\title{
Quality control of microstructure in recycled Al-Si cast alloys
}

Prof. Ing. Eva Tillová, PhD., Ing. Mária Chalupová, Ing. Lenka Hurtalová, Ing. Emília Ďuriníková

Department of Materials Engineering, Faculty of Mechanical Engineering, University of Žilina, Univerzitná 8215/1, 010 26,

Žilina, Slovak Republic. E-mail: eva.tillova@fstroj.uniza.sk

Using recycled aluminium cast alloys is profitable in many aspects. Secondary aluminium produced from recycled metal requires only $2.8 \mathrm{kWh} / \mathrm{kg}$ of metal produced and creates only about $5 \%$ as much $\mathrm{CO}_{2}$ as by primary production. Improved mechanical properties of recycled (secondary) hypoeutectic Al-Si cast alloys are strongly dependent upon the distribution and the shape of the silicon particles; the morphology, type and distribution of the second phases, which are in turn a function of alloy composition and cooling rate. The presence of additional elements as $\mathrm{Mg}, \mathrm{Mn}, \mathrm{Fe}$, or $\mathrm{Cu}$ allows many complex intermetallic phases to form, which make characterisation non-trivial. They are added deliberately to improve and to provide special material properties. Controlling the microstructure is, therefore, very important. A combination of different analytical techniques (light microscopy upon black-white etching; scanning electron microscopy (SEM) upon deep etching and energy dispersive X-ray analysis (EDX); quantitative phase analyse upon Image analyzer NIS Elements 3.0) were therefore been used for the quality control of microstructure in recycled AlSi9Cu3 cast alloy.

Keywords: recycled Al-Si cast alloys, microstructure, intermetallic phases

\section{Acknowledgements}

This work has been supported by Scientific Grant Agency of Ministry of Education of Slovak republic $N^{\circ} 1 / 0249 / 09$ and $N^{0} 1 / 0841 / 11$.

\section{References}

[1] DAS, S. K.; GREEN, J. A. S.; KAUFMAN G. J.; et al. Aluminum Recycling - An Integrated, Industrywide Approach. JOM, 2010, Vol. 62, No. 2, pp. 23-36.

[2] DAS, S. K.; GREEN J.. A. S.; Aluminium Industry and Climate. Change - Assessment and Responses. JOM, 2010, Vol. 62, No. 2, pp. 27-31.

[3] GESING, A.; WOLANSKI, R.. Recycling Light Metals from End of Life Vehicles. JOM, 2001, pp.21-23.

[4] LASA L.; RODRIGUEZ-IBABE J. M. 2004. Evolution of the main intermetallic phases in Al-Si-Cu-Mg casting alloys during solution treatment. Journal of Materials Science, 2004, 39, pp.1343-1355.

[5] TAYLOR, J. A. The effect of iron in Al-Si casting alloys. In. $35^{\text {th }}$ Australian Foundry Institute National Conference, 2004. Adelaide, South Australia, pp.148-157.

[6] MICHNA, Š.; LUKÁČ, I. a kol.; Encyklopedie hliníku. 2005, Adin s.r.o. Prešov. in Czech, p. 700, ISBN 80-89041-884.

[7] TILlOVÁ, E.; CHALUPOVÁ, M.. Štruktúrna analýza zliatin Al-Si. 2009, EDIS Žilina, Žilina, in Slovak. p. 191, ISBN 978-80-554-0088-4

[8] MICHNA, Š.; VOJTECH, D.; MAJRICH, P.; Problematika kvality Al taveniny při liti automobilových diskú, Strojírenská technologie, 2008, roč. XIII, č. 3, p. 17-23.

[9] VAJSOVA, V.; MICHNA, Š.; Optimalizace homogenizačního žíháni slitiny AlZn5,5Mg2,5Cu1,5 In. Strojírenská technologie, 2010, roč. XV, č. 3 p. 6-11.

[10] SEIFEDDINE, S.; SVENSSON, I. L. The influence of Fe content and cooling rate on the microstructure and mechanical properties of a 380-die-casting alloy. In. Vikteffektiva lättmetallstukturer, Vilmer project - Rapport 11, 2007, p. 16, Jönköping University, Sweden.

[11] SHABESTARI S. G. The effect of iron and manganese on the formation of intermetallic compounds in aluminumsilicon alloys. Materials Science and Engineering A, 383, 2004. pp. 289-298.

[12] SAMUEL, A. M.; SAMUEL, F. H. Effect of alloying elements and dendrite arm spacing on the microstructure and hardness of an Al-Si-Cu-Mg-Fe-Mn (380) aluminium die-casting alloy. Journal of Materials Science, 1995, 30, pp. 1698-1708.

[13] SAMUEL, A. M.; SAMUEL, F. H.; DOTY, H. W. Observations on the formation of $\beta$-AlFeSi phase in 319 type Al-Si alloys. Journal of Materials Science, 1996, 31, pp. 5529-5539.

[14] TILlOVÁ, E.; CHALUPOVÁ, M.; HURTALOVÁ, L. Evolution of the Fe-rich phases in Recycled AlSi9Cu3 Cast Alloy during Solution Treatment. Communications, 2010, 4, pp. 95-101.

[15] BOLIBRUCHOVÁ, D.; TILLOVÁ, E. Zlievarenské zliatiny Al-Si. 2005, EDIS Žilina, Žilina, in Slovak. p.180, ISBN 80-8070-485-6 
[16] TILlOVÁ, E.; CHALUPOVÁ, M. Study of eutectic silicon morphollogy in Al-Si alloys. Transaction of the Universities of Košice, mimoriadne číslo-Alluminium '07, 2007, pp. 17-23.

[17] MARTINKOVIČ, M. Kvantitatívna analýza štruktúry materiálov. 2010. STU Bratislava, p. 109, in Slovak.

[18] BELAN, J. Influence of cooling rate on $\gamma^{\prime}$ morphology in cast Ni - base superalloy. Acta Metalurgica Slovaca, 2011, vol. 17,1 , pp. $38-44$.

[19] VAŠKO, A. Analysis of the factors influencing microstructure and mechanical properties of austempered ductile iron. Communications, 4, 2009, pp. 43-47.

[20] DOBRZAŃSKI, L. A.; MANIARA, R.; KRUPIŃSKI, M.; SOKOLOWSKI, J. H. Microstructure and mechanical properties of AC AlSi9CuX alloys. Journal of Achievements in Materials and Manufacturing Engineering - JAMME, 2007, Vol. 24, 2, pp. 51-54.

[21] DOBRZAŃSKI, L. A.; MANIARA, R.; SOKOLOWSKI, J. H. The effect of cast Al-Si-Cu alloy solidification rate on alloy thermal characteristics. Journal of Achievements in Materials and Manufacturing Engineering - JAMME, 2006, Vol. 17, 1-2, pp. 217-220. 